\section{Speedy genes}

THE technique of transferring foreign genes into living cells by coating inert gold particles with DNA and literally bombarding them through the cell membrane has been fairly well documented for plants. But the successful application to mammalian somatic cells now reported by N.-S. Yang et al. (Proc. natn. Acad. Sci. U.S.A. 87, 9568-9572; 1990) suggests that the method may prove of value for gene therapy. Five different reporter genes were coated onto gold beads and, by accelerating them at high voltage, were successfully introduced and expressed in rodent liver, skin and muscle tissue. The method works equally well in vitro with a variety of cultured cell lines, and offers a potentially useful alternative to viral gene transfer.

\section{Getting tough}

RESEARCHERS at Los Alamos National Laboratory have discovered a new way of toughening the surfaces of ceramics - a vital step if these hard but brittle materials are to be put to widespread use in mechanical engineering. Silicon carbide, one of the hardest materials known, is liable to fracture owing to defects on its surface. But T. R. Hervis, J.-P. Hirvonen and M. Nastasi (J. Mater. Sci. 6, 146-151; 1991) find that incorporating titanium into the $\mathrm{SiC}$ surface, using laser heating, has dramatic effects on the material's properties: surface cracking and flaking can be prevented almost entirely. Similar results have been achieved using ion implantation of titanium, but the new process, involving the evaporation of a thin layer of titanium onto the ceramic's surface followed by rapid heating in air by an excimer laser, is more convenient, faster and produces a surface that is in thermal equilibrium. A puzzling variation of friction with humidity apparently has no effect on the durability.

\section{How cats purr}

THE gentle purring of contented cats results from laryngeal modulation of respiratory flow, as shown by D. E. Frazer Sissom et al. (J. Zool., Lond. 223, 67-78; 1991). The authors' comprehensive monitoring of obliging domestic cats (Felis silvestrisf. catus) with oscilloscopes and sound recording equipment revealed that the sound emanates from the oscillation of the vocal folds as the cat inhales and exhales. This is independent of phonation, the pitch of which is controlled by stretching of the vocal chords, which explains why cats can purr and mew at the same time. Purr frequency is independent of age, size, weight and sex, and ultimate control is exercised by an oscillator in the brain. Parallel studies of purring in cheetahs (Acionyx jubatus) and pumas (Puma concolor) were understandably less thorough, but yielded similar results.

$\mathrm{V} \beta$-selective elements and their linkage to retroviruses

\begin{tabular}{|c|c|c|c|c|c|}
\hline Vbse & $\mathrm{V} \beta$ & $\mathrm{MHC}$ & Chromosome & Retrovirus & Reference \\
\hline MIs-1a & $6,8.1,9 *$ & $\mathrm{II}, \mathrm{E}>\mathrm{A}$ & 1 & Mtv-7 & 6 \\
\hline MIs-2a & 3 & $E>>A$ & 4 & Mtv-13 & 6 \\
\hline MIs-3a & 3 & $E>>A$ & 16 & Mtv-6 & 6 \\
\hline MIs-2-like & 3 & $?$ & 7 & Mtv-1 & 6. R. Abe (pers. comm.) \\
\hline Etc-1 (Dvb 11-2) & $5.1,5.2,11$ & $\mathrm{E}$ & 12 & Mtv-9 & $4,7,8$ \\
\hline Dvb11-1 & 11 & $\mathrm{E}$ & 6 & Mtv-8 & 8 \\
\hline Dvb11-3 & 11 & $\mathrm{E}$ & 14 & Mtv-11 & 8 \\
\hline Unnamed & 14 & $\mathrm{E}$ & Extrinsic & MMTV & 5 \\
\hline MAIDS B cell & 5 & II & Extrinsic & MuLV & 9, H. C. Morse (pers. comm.) \\
\hline Unnamed & $17 a$ & $\mathrm{E}$ & Not mapped $\dagger$ & $?$ & 29,30 \\
\hline Unnamed & 12 & $\mathrm{E}$ & Not mapped & ? & 31, R. J. Hodes (pers. comm.) \\
\hline Unnamed & 16 & $E$ & Not mapped & ? & 31 , R. J. Hodes (pers. comm.) \\
\hline Unnamed & $19 a$ & $\mathrm{E}$ & Not mapped & $?$ & R. J. Hodes (pers. comm.) \\
\hline
\end{tabular}

* Mls- $1 \mathrm{a}$ is often stated to delete $V \beta 7$ as well, but this is not always confirmed (R. Abe, personal communication).

$\dagger$ Non-polymorphic

tioned. One issue raised by the new findings is why retroviruses encode Vbse, and why mice retain such large numbers of these sequences in their genome. Stimulation in vivo with Vbse $\mathrm{e}^{1,20}$ is known to induce widespread immune suppression, so onc possibility is that retroviral Vbse facilitate viral invasion of the host by suppressing the immune response; alternatively, activation of $T$ cells by retroviral Vbse may make them susceptible to retroviral infection, facilitating spread of the virus. The mouse may counter these strategies by retaining viral sequences which eliminate those $\mathrm{T}$ cells able to respond to viral Vbse.

The previously undefined nature of $M l s$ genes has led several groups to study a similar T-cell response driven by the bacterial toxic mitogens ${ }^{1+.21}$. These substances cause food poisoning, toxic shock syndrome and other human disorders. They are potent mitogens for $\mathrm{T}$ cells whose receptors are encoded by one or a few $\mathrm{V} \beta$ gene segments, require class II MHC molecules to stimulate, act selectively on CD4 $T$ cells, and cause clonal deletion of developing $\mathrm{T}$ cells. Thus, the bacterial toxic mitogens were thought to be possible homologues of endogenous Vbse $\mathrm{V}^{22}$. If so, they seem to have achieved this result by a distinct evolutionary pathway, because they show no structural similarity to endogenous retroviral genes. An alterna-

Kappler, J. et al. Nature 332. 35-40 (1988).

MacDonald. H.R. et al. Nature 332, 40-45 (1988)

. Festenstein. H. Transplant. Rev 15, 62-88(1973)

4. Woodland, D et al. Science 247, $964-967$ (1990)

5. Marrack, P., Kushnir, E. \& Kappler, J. Nature 349 $524-526(1991)$

6. Frankel, W.N., Rudy, C., Coffin, J.M. \& Huber, B.T. Nature 349, $526-528$ (1991)

Woodland, D.L., Happ. M.P., Gollob, K. J. \& Palmer, E Nature 349. 529-530 (1991).

8. Dyson, P.J., Knight, A.M., Fairchild, S., Simpson, E. \& Tomonari. K. Nature 349, 531-532 (1991).

9. Hugin, A.W. Vacchio. M.S. \& Morse, H.C. III (manuscript submitted).

10. Davis, M.M. \& Bjorkman, P.J. Nature 334, 395-402 (1988)

11. Pullen, A.M. et al Cel/61, 1365-1374 (1988)

12. Choi, Y. et al. Nature 346, $471-473(1990)$

12. Choi, Y. et al. Nature 346, $471-473(1990)$.

14. Janeway, C.A. Jr et al. Immun. Rev. 107, 61-88 (1989).

15. King, L.B. et al. J. Immun. 144, 3218-3227 (1990)

16. Webb, S.R. et al. J. exp. Med 169, 1-12 (1989).

17. Ryan, J.J. et al. J. Immun. 130. 1063-1073 (1983) tive hypothesis is that the bacterial toxic mitogens act on the endogenous Vbse, mimicking their effects by perturbing their structure $^{2.3}$. If so, then all species whose $\mathrm{T}$ cells respond to bacterial toxic mitogens must have Vbse, most notably humans. Although less is known about endogenous retroviruses in man, possible retroviral insertions have been reported ${ }^{24}$. The new findings should allow a rapid definition of Vbse genes in several species.

The fact that Vbse may be encoded by a retrovirus and act primarily on $\mathrm{CD} 4 \mathrm{~T}$ cells raises the question of whether the most notorious retrovirus, the human immunodeficiency virus (HIV), which causes AIDS, may also encode a Vbse that is involved in pathogenesis. CD4 T-cell depletion in AIDS could occur as follows. HIV infects CD 4 T cells, remaining latent until the $\mathrm{T}$ cell is activated. As activated human $\mathrm{T}$ cells express MHC class II proteins, HIV-infected CD4 T cells would express both HIV retroviral proteins and MHC class II, allowing them to interact with $\mathrm{T}$ cells expressing a complementary $\mathrm{V} \beta$. It has recently been shown that activated human $\mathrm{T}$ cells presenting bacterial toxic mitogens induce inactivation of cells expressing the corresponding $V \beta^{25}$. Furthermore, in vivo administration of bacterial toxic mitogens $\mathrm{s}^{2 \mathrm{~h}}$ or Mls-disparate cells $^{27}$ leads first to activation and then to profound depletion of CD4 $\mathrm{T}$ cells

18. Coffin, J.M. in Virology (ed. Fields, B.N.) 1437-1500 (Raven, New York, 1990)

19. Jacobsson, J., Lilliehook, B. \& Blomgren, J. Scand. J. Immun. 4. 181-191 (1975)

20. Pinto, M., Torten, M. \& Birnbaum, S.C. Transplant. 25 $320(1978)$.

21. Marrack, P. \& Kappler, J. Science 248, 705-711 (1990).

22. Janeway, C.A. Jr Cel/63, 659-661 (1990)

23. Janeway, C.A. Jr, Rath, S. \& Yagi, J. Behring inst. Mitteilungena (in the press).

24. Silver, J. et al. Molec cell. Biol. 7, 1559-1562 (1987).

5. OHehir, R.E. \& Lamb, J.E. Proc. natn. Acad. Sci. U.S.A. 87. $8884-8888$ (1990).

Kawabe, Y. \& Ochl, A. Nature 349, 245-248(1991).

27. Webb. S.R., Morris, C. \& Sprent, J. Cell 63, 1249-1256 (1990)

28. Coffin, J.M. Cell 46. $1-4(1986)$

29. Kappler, J.W. et al. Cell 49. 273-280 (1987)

30. Marrack, P. \& Kappler, J. Nature 332. 840-843 (1988).

1. Vacchio M.S., Ryan, J.J. \& Hodes, R.J. J. exp. Med. 172, $807-813(1990)$. 